\title{
THE IMPORTANCE OF APPLYING THE GENDER EQUALITY PRINCIPLE AT INSTITUTIONAL LEVEL
}

\author{
A. Cordoş
}

\author{
Alexandru Cordoş \\ Agora University of Oradea, Romania \\ PhD Professor, Faculty of Law and Economics, Social Sciences Department \\ *Correspondence: Elena-Ana Nechita, Agora University of Oradea, No.8, Piaţa \\ Tineretului, Oradea, Romania, Tel: 004/0735608317 \\ E-mail: anaelena2009@yahoo.com
}

\begin{abstract}
:
Gender equality, as a fundamental principle of the European Union, is included in a series of legislative and non-legislative documents ${ }^{1}$ recommending a balanced participation of both genders in the drafting and adoption of major decisions in the political and social fields, as a vital component in the development of a real democracy and a decisive factor of economic growth.

In terms of the degree of labour employment, gender equality is reflected in the need to promote equally women and men in the labour market, particularly in leading positions.

According to the European Commission's report ${ }^{2}$, women in European countries are still underrepresented in leadership positions, although there has been some general progress. Compared to the situation recorded ten years ago, at EU level, there was an increase by 16\% of women involved in politics and appointed to ministerial posts.

The drafting of the first National Strategy on Equal Opportunities for Women and Men adopted by Government Decision no. 319/2006 approving the National Strategy on Equal Opportunities for Women and Men for the period 2006-2009 and of the General Action Plan for Implementing the National Strategy on Equal Opportunities for Women and Men for the period 2006-2009.

This shows that women in Romania still experience gender discrimination, and this is true for areas of economy where women are the majority, as well as for those where men are the majority. The result is the emergence of occupational gender segregation, feminized occupational fields are generally lower paid. Although progress has been made both in the field of education and that of labour employment, women still have many obstacles to pass before achieving real equality.

The efforts to be made in order to strengthen gender equality must address not only the improvement of legislation in the field of opportunity and gender equality,

\footnotetext{
${ }^{1}$ Decision of the European Council in Madrid of 1995 on the annual monitoring of the implementation of the Beijing Platform for Action adopted during the $4^{\text {th }}$ UN Conference on Women held in Beijing in 1995, the European Pact for Gender Equality adopted by the European Council in 2006 and renewed in 2010, the Charter of Fundamental Rights of the European Union, the 2020 EU Strategy for Smart, Sustainable and Inclusive Growth, the European Strategy for Equality between Women and Men 20102015, the European Pact for Gender Equality 2011-2020, the EPSCO Council conclusions and the European Commission's communications inviting to promote and strengthen equality between women and men in various fields or the European Commission's annual Reports on the progress made in the field of equality between women and men, etc.

${ }^{2}$ European Commission's annual report on progress in gender equality -2010
} 


\section{THE IMPORTANCE OF APPLYING THE GENDER EQUALITY PRINCIPLE AT INSTITUTIONAL LEVEL}

but also a change in attitudes and behaviours, in social structures, so as to allow women to develop their personality according to their own will and be actively involved in all areas of life.

Key words: equal opportunities, gender equality, non-discrimination, workforce, institutions.

\section{Introduction}

Gender equality is a constant concern of modern society, as proved by numerous documents issued by international institutions seeking equal participation of women and men in the development of family and society.

The International Labour Organization was the promoter of recommendations aimed at the observance of equal treatment, and to this end, in year 1951, it adopted the Recommendation 90/1951 concerning Equal Remuneration for Men and Women Workers for Work of Equal Value.

The principle of equality between women and men has been recognized since its creation by the European Community through documents intended to impose on the Member States the guarantee of equal rights in terms of social protection, employment, remuneration and professional training of EC citizens.

The first steps towards the enforcement of equal treatment and the exclusion of discrimination between women and men were taken through the adoption of Council Directive $75 / 117 /$ EEC of $10^{\text {th }}$ February 1975 on the approximation of the laws of Member States relating to the implementation of the principle of equal pay for men and women workers, a document providing for equal pay for work of equal value.

The 1992 Maastricht Treaty extended the powers of the European Union, an important place being given to the field of equal opportunities. The principle of gender integration was considered, stating that "in all its activities, the Community shall aim to eliminate inequalities and promote equality between men and women"

Also, measures aimed at combating "discrimination based on sex, racial or ethnic origin, religion or belief, disability, age or sexual orientation" ${ }^{4}$ were provided for.

In order to strengthen the determination in promoting equal opportunities, the Treaty also stipulates that each Member State must ensure "equal opportunities for men and women in terms of opportunities in the labour market and treatment in the workplace"s, as well as the implementation of the principle of equal pay for equal work or work of equal value"6 among male and female workers.

Subsequently, the Community acquis was enriched by a series of regulatory acts aimed at applying the principle of equal opportunities for women and men in important areas, such as protection against risks of sickness, disability, unemployment, etc. There was also interest in providing equal opportunities in terms of the occupational schemes for self-employed activities.

The first important directive dealing with equal opportunities was Council Directive 76/207/EEC on the implementation of the principle of equal treatment for men and women as regards access to employment, vocational training and promotion, and working conditions. This directive was amended by Council Directive

\footnotetext{
${ }^{3}$ Article 3 of the Maastricht Treaty

${ }^{4}$ Article 13 of the Maastricht Treaty

${ }^{5}$ Article 137 of the Maastricht Treaty

${ }^{6}$ Article 141 of the Maastricht Treaty
} 
2007/73/EEC defining equal treatment as "no discrimination whatsoever on the grounds of sex, either directly or indirectly, by reference in particular to marital or family status"?.

In the course of time, the European Community's concern with eliminating inequalities and promoting equality between women and men increased, which led to the adoption of several documents meant to ensure equal opportunities for women and men in the labour market and equal treatment in the workplace in the Member States.

To this end, the following acts were adopted: Council Directive 79/7/EEC of $19^{\text {th }}$ December 1978 on the progressive implementation of the principle of equal treatment for men and women in matters of social security, Council Directive no. 92/85/EEC of $19^{\text {th }}$ October 1992 on the introduction of measures to encourage improvements in the health and safety at work of pregnant workers and workers who have recently given birth or are breastfeeding, Council Directive 2004/113/EC of $13^{\text {th }}$ December 2004 implementing the principle of equal treatment between men and women in terms of access to and supply of goods and services, the European Parliament and Council Directive 2006/54/EC of $5^{\text {th }}$ July 2006 on the implementation of the principle of equal opportunities and equal treatment for men and women in matters of employment and occupation (recast), Council Directive 2010/18/EU of $8^{\text {th }}$ March 2010 implementing the revised Framework Agreement on parental leave concluded by BUSINESSEUROPE, UEAPME, CEEP and ETUC and repealing Directive 96/34/EC, European Parliament and Council Directive 2010/41/EU of $7^{\text {th }}$ July 2010 on the application of principle of equal treatment between men and women engaged in an activity in a self-employed capacity and repealing Council Directive 86/613/EEC.

Also, the European Court of Human Rights ruled in numerous cases that the "the right not to be discriminated against in the enjoyment of rights guaranteed under the Convention is violated not only when states treat differently persons in analogous situations, without providing an objective and reasonable justification, but also when States without an objective and reasonable justification fail to treat differently persons whose situations are significantly different"

On the grounds of these documents the European Commission developed the Strategy for equality between women and men 2010-1015 which includes actions aimed mainly at women's economic independence, equal pay, equality in decisionmaking, dignity, integrity and an end to gender-based violence.

This strategy was the result of the 2006-2010 Roadmap for Equality between women and men, resuming priorities defined in Women's Charter, constituting the Commission's work program and describing the key actions set for the period between 2010 and 2015. The strategy represented at the same time "a basis for cooperation between the Commission, the other EU institutions, Member States and other stakeholders in the European Pact for Equality between Women and Men"9.

Given the efforts made at European level in order to implement the principle of equal opportunities, Romania, too, joined these efforts, especially when starting its integration into the European Community.

\footnotetext{
${ }^{7}$ Art. 3, point (1) of Council Directive 2002/73/EEC amending Council Directive 76/2007/EEC

${ }^{8}$ ECHR Decision in case Thlimmenos versus Greece of April 2000 in Hotărâri ale Curţii Europene a Drepturilor Omului, Culegere selectivă (Decisions of the European Court of Human Rights, Selective Collection), Vol. III, Publishing House Polirom, Iaşi, 2003, p. 219

${ }^{9} \mathrm{http}$ ://europa.eu/legislation_summaries/employment_and_social_policy/equality_between_men_and_ women/em0037_ro.htm
} 
The first step in this field was the adoption of the Government Ordinance no. $137 / 2000$ on preventing and sanctioning all forms of discrimination by which the State guarantees, through the new institution established, namely the National Council for Combating Discrimination, equality among its citizens, the exclusion of privileges and discrimination in the exercise of their fundamental rights and freedoms.

At the end of year 2000, Government Decision no. 1273 regarding the approval of the National Plan of Action for Equal Opportunities for Women and Men was developed and approved, which is "the expression of the politic commitment to assure and guarantee that all citizens are equal and marks the Romanian Government's efforts to eliminate any discrimination based on race, nationality, ethnical origin, language, religion, gender, opinion, political affiliation, property or social origin, pursuant to Art. 4, para. (2) in the Constitution of Romania"10.

The adoption of Law no. 202/2002 on equal opportunities and equal treatment between women and men followed, which partially transposed Directive 2006/54/EC of the European Parliament and of the Council of $5^{\text {th }}$ July 2006 on the implementation of the principle of equal opportunities and equal treatment for men and women in matters of employment and occupation (recast), as well as Directive 2010/41/EU of the European Parliament and of the Council of $7^{\text {th }}$ July 2010 on the application of principle of equal treatment between men and women engaged in an activity in a selfemployed capacity and repealing Council Directive 86/613/EEC. Through this regulatory act, measures for promoting equal opportunity and treatment for women and men were regulated, in order to eliminate all forms of discrimination, the Ministry of Labour, Family, Social Protection and the Elderly, through the Department for Equal Opportunities between Women and Men, being the institution charged with the responsibility of ensuring compliance and the control of the implementation of the law in its field of activity, through the institutions subordinate to it, which are under its authority or coordination, institutions responsible for implementing these measures.

In the process of negotiating Romania's accession to the European Union, it was agreed upon a new institutional construction ensuring the development and promotion of public policies on equal opportunities, as well as compliance with relevant legal provisions.

Thus, through Government Ordinance no. 84 of $19^{\text {th }}$ August 2004 amending and supplementing Law no. 202/2002 on equal opportunities between women and men, the National Agency for Equal Opportunities between Women and Men (ANES) was established, as a specialized body of the central public administration, with legal personality, subordinate to the Ministry of Labour, Social Solidarity and Family.

The Agency's objective was to promote the principle of equal opportunities and treatment between men and women and to ensure active integration from gender perspective into all national policies and programmes.

\section{GENDER EQUALITY IN DECISION-MAKING POSITIONS}

We can define the decision-making position as a "position in which it is possible to make a decision or influence a decision".

The legislation on gender equality provides for balanced access to decisionmaking positions, as follows:

\footnotetext{
${ }^{10}$ Government Decision no. 1273 regarding the approval of the National Plan of Action for Equal Opportunities for Women and Men
} 


\section{A. Cordoş}

"Art. 21. (1) Public authorities, both central and local, economic and social units, as well as political parties and other non-profit entities, which carry out their activity on the grounds of their own statutes, promote and support the balanced participation of women and men in leadership and decision-making.

(2) The provisions of Para. (1) also apply to the nomination of the members and/or participants in any council, group of experts and other lucrative managerial and/or consulting structures.

Art. 22. In order to accelerate the achievement of de facto equality between women and men central and local public authorities will adopt incentives for fair and balanced representation of women and men in decision-making authorities of the social partners, respecting the criteria of competence" 11 .

Until the dissolution of the National Agency for Equal Opportunities between Women and Men (ANES) and the establishment of the Department for Equal Opportunities between Women and Men within the Ministry of Labour, Family and Social Protection in year 2009, it conducted various studies focused on equal opportunities in the Romanian institutional system.

One such study, "Women's Participation in Political Life in Romania", analyzed data collected after the general elections in 2004, and the results obtained led to the formulation of several conclusions:

"(1) The feminization of "middle" decision-making levels of public administration (particularly at central level). The pyramid of political power is dominated both on top and at the bottom, by men.

(2) The feminization of areas such as justice, health, European integration and labour field.

(3) (The former) Ministry of European Integration is the only ministry in which over $75 \%$ of the management positions are held by women, followed by the Ministry of Culture (61.02\%), the Ministry of Health (60.24\%) and the Ministry of the Environment (58.72\%).

(4) As regards local public administration, women are under-represented, given that, in general, over $80 \%$ of the decision-making positions are occupied by men"12.

A second study on the same topic, entitled "An Analysis on the Participation of Women and Men in the Decision-Making Process at Central and Local Government Level", conducted in year 2009, had as initial data the situation of the participation of both genders in the general elections of year 2008, as well as the European Parliament elections of year 2009.

Upon completion of the study, the following conclusions were drawn:

"(1) As regards the situation of women's participation in the first and second decision-making levels within the ministries, it is observed that the percentage of positions occupied by women increases with the decrease of the decision-making level.

(2) Compared with the average of parliaments of EU countries (24\%) and with the percentage in the European Parliament during the 2004-2009 term (31\%), Romania has a parliamentary representation of women of only $9.76 \%$, according to the 2008 parliamentary election results.

(3) Compared to the 2004-2008 period, we notice a decrease in the level of participation of women in the decision-making process within the local

\footnotetext{
${ }^{11}$ Law no. 202/2002 on equal opportunities and equal treatment between women and men

12 "Women's Participation in Political Life in Romania" Study, National Agency for Equal Opportunities between Women and Men, 2005
} 


\section{THE IMPORTANCE OF APPLYING THE GENDER EQUALITY PRINCIPLE AT INSTITUTIONAL LEVEL}

administration, both in terms of their presence in the local and county councils, and at the level of the Prefect's Institution"13.

In its turn, the Department for Equal Opportunities between Women and Men conducted, in year 2011, a study on the distribution of women and men in leadership positions, analyzing data received from the Ministry of Labour, Family and Social Protection, the Ministry of Public Finance, the Ministry of Transport and Infrastructure, the Ministry of Regional Development and Tourism, the Ministry of Health, the Ministry of Agriculture and Rural Development, the Ministry of National Defence, the Ministry of Administration and Interior, the Ministry of Foreign Affairs, the Ministry of Communications and Information Society, the Ministry of Justice, the Ministry of Education, Research, Youth and Sports, the Ministry of Economy, Trade and Business Environment, the Ministry of Environment and Forests, the Ministry of Culture and National Heritage, the Department for European Affairs, the General Secretariat of the Government and the Department for Relations with Parliament.

"Institutions with female prevalence, grades 1 and 2, A and B levels

(1) By interpreting each institution as an independent entity, the ministries with female prevalence - the top 5 , with over $50 \%$ women represented in decisionmaking positions - are as follows: positions.

1. The Ministry of Health, where women hold $61.75 \%$ decision-making

2. The General Secretariat of the Government, with $59.93 \%$ women in decision-making positions.

3. The Ministry of National Defence, with $59.77 \%$ women at decision-making level.

4. The Ministry of Labour, Family and Social Protection, with 58.80\% women in decision-making positions.

5. The Ministry of Economy, Trade and Business Environment (without representation at B level) with 57.14\% women in decision-making positions.

(2) The share of women in the ministries (level A), decision grades 1 and 2

1. The Ministry of Labour, Family and Social Protection: $73.91 \%$

2. The Ministry of Public Finance: $71.14 \%$

3. The Ministry of Justice: $70.97 \%$

(3) The share of women in institutions (level B), decision grades 1 and 2

1. The General Secretariat of the Government: $62.06 \%$

2. The Ministry of Health: $61.74 \%$

3. The Ministry of Foreign Affairs: $60 \%$

(4) Institutions with male prevalence, grades 1 and 2, levels A and B

1. The Ministry of Culture and National Heritage: $67.21 \%$

2. The Ministry of Justice: $63.38 \%$

3. The Ministry of Foreign Affairs: $57.14 \%$

4. The Ministry of Environment and Forests: $56.73 \%$

5. The Ministry of Agriculture and Rural Development: 56.36\%.

(5) The share of men in the ministries (level A), decision grades 1 and 2

1. The Ministry of Education, Research, Youth and Sports: $64.71 \%$

2. The General Secretariat of the Government: $62.50 \%$

3. The Ministry of Foreign Affairs: 59.62\%

\footnotetext{
${ }^{13}$ www.mmuncii.ro/Studiu "An Analysis on the Participation of Women and Men in the DecisionMaking Process at Central and Local Government Level" Study, National Agency for Equal Opportunities between Women and Men, 2009
} 
(6) The share of men in institutions (level B), decision grades 1 and 2

1. The Ministry of Culture and National Heritage: $80.95 \%$

2. The Ministry of Transport and Infrastructure: $70.27 \%$

3. The Ministry of Justice: $64.66 " .{ }^{14}$

\section{Conclusions}

Considering the fact that after the approval of the Government Decision no. $1273 / 2000$ and the adoption of Law no.202/2002 no progress was felt in the implementation of the National Plan a decision was taken to approve Decision no. 285 of $4^{\text {th }}$ March 2004 on the implementation of the National Action Plan for Equality between Women and Men, which established the minimum measures for achieving the objectives of the National Action Plan for Equality between Women and Men, and the implementation of these measures represented an obligation for all public authorities and institutions. Thus, the Inter-Ministerial Advisory Commission for Equal Opportunities between Women and Men (CODES) was established, which follows and monitors the progress made in implementing measures to achieve the objectives of the Plan.

The tasks of specific structures for equal opportunities for women and men included: the drafting of annual reports on the representation of women and men in decision-making positions at the level of the public authority or public institution and of the structures under its coordination and/or subordination.

Studies on gender discrimination in organizations have pointed out that, although women adopt different styles of leadership, they are equally effective in leadership positions. The tendency among women is to adopt a democratic management style, whereas men generally adopt a more autocratic style.

The results of studies on the involvement of women and men in decisionmaking positions in public administration reveal that negative gender discrimination is diminished from one stage of the study to another, already having positive values in certain institutions.

Thus, we can say that, in year 2012, at national level, more than half of the decision-making positions in central public administration were held by women. At ministerial level, most decision-making positions are held by women. Their share in decision-making positions both of grade 1 and grade 2 is greater than the one at national level, with a mention that the share of women in decision-making positions corresponding to decision-making grade 1 is smaller than that of women occupying decision-making positions corresponding to decision-making grade 2 .

Also, studies have confirmed that the share of women in decision-making positions in the ministries is higher as compared to the share of women in the same positions in decentralized units of the ministries, cumulated with that of women in decision-making positions in institutions subordinate to/under the authority of ministries and with that calculated at the level of other specialized bodies organized as subordinate to the ministries.

Within territorial institutions, subordinate to the ministries, the gender gap in holding positions may be considered as non-existing, with women and men equally occupying decision-making positions. It is worth mentioning that the positions corresponding to decision-making grade 1 are predominantly occupied by men, and those corresponding to decision-making grade 2 are mostly occupied by women.

14 www.mmuncii.ro/Studiu "The Situation of Women and Men in Decision-Making Positions in Central Public Administration" Study, The Department of Equal Opportunities for Women and Men, 2011 
However, we must say that, for management positions associated with a lower decision-making grade, the probability that women occupy these positions is higher, a situation found both at ministerial level and in the territory. So, regardless of the decision-making grade, a higher decision-making position attracts an increased probability of being occupied by a man.

In year 2011, in central public administration, executive leadership positions of both decision-making grades are mainly occupied by women within the Ministry of Health, the General Secretariat of the Government, the Ministry of National Defence and the Ministry of Labour, Family and Social Protection.

If, within the Ministry of Labour, Family and Social Protection, the Ministry of Public Finance and the Ministry of Justice, the degree of women's participation in decision making is the highest, at local level and in institutions subordinate to/under the authority of the ministries, structures within the General Secretariat of the Government, the Ministry of Health and the Ministry of Foreign Affairs, the share of women who occupy decision-making positions is greater.

By comparison, year 2011 also reveals that the share of decision-making positions occupied by men is higher, in the Ministry of Culture and National Heritage, the Ministry of Justice, the Ministry of Foreign Affairs, the Ministry of Environment and the Ministry of Agriculture and Rural Development.

At local level and in institutions subordinate to/under the authority of the Ministry of Culture and National Heritage, the Ministry of Transport and Infrastructure and the Ministry of Justice, we find the largest share of men in decisionmaking positions.

Gender equality provides the same level of respect, same opportunities to make choices, as well as the same level of decision-making. These equal rights are reflected in all aspects of human development, including the economic, social, cultural, civil and political areas.

For this goal to become true it is necessary to put the idea into practice and, most importantly, to change collective consciousness.

However, the existence of opportunity discrimination is still a reality, despite the assertion of supporting the principle of equal opportunities. In this situation public institutions must take all necessary legal steps towards preventing the discriminations that might occur, directly or indirectly, in the recruitment of staff, as well as the management of staff's careers.

Having emphasized this issue, it is essential for public institutions to promote equal treatment and equal opportunities, in accordance with the requirements of social promotion, of integration and cohesion through work, in order to become more effective for the society they serve.

The action to be taken in this direction consists in ensuring the promotion of equality in all public positions and preventing all forms of discrimination in ensuring free access to public services, to career development.

The necessary steps should focus on actions of public information carried out before the start of the recruitment process in order to ensure equal access for everyone to public positions. They should be supplemented by monitoring the recruitment conditions so that there are no premises for discrimination. Also, real opportunities for professional career development should be provided for the entire staff, guaranteeing equal treatment on all levels of management. The purpose of these measures is to provide an effective education and training of the civil servants in public institutions, as well as to promote good practice examples in order to prevent discrimination of any kind. 
At national level, following the regional and European trend, we must seek and implement new solutions at legal and institutional level for the application of the principle of equality and non-discrimination as a guarantee of the promotion and protection of human rights. In this direction, a major part is played by public institutions, as well as national institutions and bodies involved in guaranteeing human rights, respect for equal opportunities and non-discrimination, and also Romanian Parliament.

\section{Bibliography}

\section{National Legislation}

1. Law no. 202 of $19^{\text {th }}$ April 2002 on equal opportunities and treatment between women and men, as subsequently amended and supplemented

2. G.E.O. (Government Emergency Ordinance/O.U.G.) Project amending and supplementing Law no. 202 of $19^{\text {th }}$ April 2002 on equal opportunities and treatment between men and women, as subsequently amended and supplemented

3. Law. no. 324/2006 amending and supplementing Government Ordinance no. $137 / 2000$ on preventing and sanctioning all forms of discrimination, published in the Official Journal of Romania, Part I, no. 626 of $20^{\text {th }}$ July 2006

4. Law no. 53/2003 - Labour Code, published in the Official Journal of Romania, Part I, no. 72 of $5^{\text {th }}$ February 2003 , as subsequently amended and supplemented

5. Law no. 168/1999 on the settlement of labour disputes

6. Law 25-2012 on preventing and combating domestic violence

7. Government Decision (HG) 237-2010 National Strategy on Equal Opportunities 2010-2012

8. 61- 2008 GEO Equal Access to Goods and Services

9. GEO (Government Emergency Ordinance) 67-2007 Equal Treatment Professional Social Security Schemes

10. Government Decision (HG) 319-2006 National Strategy on Equal Opportunities 2006-2009

11. Ordinance 137-2000 on Preventing and Sanctioning Discrimination

\section{European Union Legislation}

12. The EU Strategy for Equality between Women and Men 2010-2015

13. EP Report 22442011 Equality between Women and Men in the European Union 2011

14. 2009 Eurobarometer Gender Equality in the EU

15. 2011 Eurobarometer Women in Decision-Making Positions

16. The Maastricht Treaty

17. Council Directive 2002/73/EEC amending Council Directive 76/2007/EEC

\section{Relevant Publications in the Field of Gender Equality}

1. Realitate a tranziţiei: Discriminarea de gen (Gender Discrimination - a Reality of Transition), V. Pasti, C. Ilinca, Editura Institutului de Studii ale Dezvoltării (Publishing House of the Institute of Development Studies), Bucharest, 2001

\section{Websites}

1. www.mmuncii.ro 
2.http://europa.eu/legislation_summaries/employment_and_social_policy/equality_bet ween_men_and_women/em0037_ro.htm

*This work was performed as part of the project "PECAFROM - Promoting Equal Opportunities in University and Academic Careers for Women in Romania" POSDRU(SOPHRD)/144/6.3/S/127928, co-financed by the European Union and the Romanian Government in the European Social Fund through the Sectoral Operational Programme Human Resources Development 2007-2013. 